\title{
Erratum to: Role of somatic cells on dairy processes and products: a review
}

\author{
N. Li • R. Richoux • M. Boutinaud • P. Martin • \\ V. Gagnaire
}

Published online: 19 March 2015

(C) INRA and Springer-Verlag France 2015

\section{Erratum to: Dairy Sci. Technol. DOI 10.1007/s13594-014-0176-3}

In the original paper, the acknowledgements section should have read as follows: We are grateful to Mary Bret for the English correction of this paper and to Anne-Laure Jacquet for her bibliographic assistance. We thank the "Agence Nationale de la Recherche et de la Technologie" for funding this work (Cifre contract reference 2011/0574), the "Association de Coordination Technique pour l'Agro-alimentaire" and the "Unité Mixte de Technologie Caseolis" for their scientific support.

The online version of the original article can be found at http://dx.doi.org/10.1007/s13594-014-0176-3.

N. Li • V. Gagnaire

INRA, UMR 1253, Science et Technologie du Lait et de l'OEuf, 65 rue de Saint Brieuc,

F-35042 Rennes, France

N. Li • V. Gagnaire $(\bowtie)$

Agrocampus Ouest, UMR 1253, Science et Technologie du Lait et de l'OEuf, 65 rue de Saint Brieuc, 35042 Rennes, France

e-mail: valerie.gagnaire@rennes.inra.fr

N. Li $\cdot$ R. Richoux

Actalia, BP 50915, 35009 Rennes, Cedex, France

M. Boutinaud

INRA, UMR 1348, Physiologie, Environnement et Génétique pour l'Animal et les Systèmes d'Élevage, 35590 Saint Gilles, France

M. Boutinaud

Agrocampus Ouest, UMR 1348, Physiologie, Environnement et Génétique pour l'Animal et les Systèmes d’Élevage, 35590 Saint Gilles, France

P. Martin

INRA, UMR 1313, Génétique Animale et Biologie Intégrative, 78350 Jouy-en-Josas, France

P. Martin

AgroParisTech, UMR 1313, Génétique Animale et Biologie Intégrative, 78350 Jouy-en-Josas, France 
In addition, there is an error in the text, page 529, the last sentence of the second paragraph in Section 4.1.2, which should read as follows:

Nevertheless, the desirable but weak lipolysis observed in Swiss-type cheeses is mainly due to the ripening flora Propionibacterium freudenreichii rather than to the lipoprotein lipase being rapidly inactivated during heat treatment of cheese making (Dherbécourt et al. 2010).

Everything else in the paper remains correct. 